\title{
Sobre algunas estrategias fílmicas para una propuesta de primera persona documental
}

\section{About filmic strategies to develop a first person narrative in documentary}

\section{Catalina Donoso Pinto}

Instituto de la Comunicación e Imagen, Universidad de Chile

catalina.donoso@u.uchile.cl

\begin{abstract}
Resumen
El presente trabajo explora las relaciones entre identidad, memoria e infancia en dos documentales chilenos recientes: El edificio de los chilenos de Macarena Aguiló y El eco de las canciones de Antonia Rossi. El análisis enfatiza el uso de los recursos fílmicos en cada una de estas cintas al construir una primera persona documental, y de esta manera, se busca cuestionar las nociones antes mencionadas como conceptos fijos y definitivos.
\end{abstract}

Palabras clave: Identidad, memoria, infancia, documental chileno.

\begin{abstract}
This article explores the connections among identity, memory and childhood in two recent Chilean documentaries: El edificio de los chilenos de Macarena Aguiló y El eco de las canciones de Antonia Rossi. The analysis emphasizes the way each documentary uses its filmic resources to develop a first person narrative, questioning the notions already mentioned, as fixed and definitive concepts.
\end{abstract}

Keywords: Identity, memory, childhood, Chilean documentary.

En Los rubios, la comentada cinta de la realizadora argentina Albertina Carri, vemos a su directora falseada en cámara por una actriz que toma su lugar y representa su historia. Vemos también cómo la verdadera protagonista de los hechos convive en escena con su doble cinematográfico e, incluso, este la acompaña a hacerse el examen de sangre que probaría -ilógicamente- el parentesco con sus padres, ejecutados 
políticos. Vemos, en suma, la problematización de esa voz, esa presencia enunciativa que se propone revisar el pasado y reconstruir el espacio opaco de la memoria; asistimos a la puesta en abismo de los mecanismos de la memoria, a partir del mismo ejercicio reflexivo del aparato cinematográfico; porque no es solo la posibilidad de recordar lo que se cuestiona, sino las posibilidades del filme para representarla.

Partiendo entonces de la posición enunciativa como un problema a revisar desde el documental autobiográfico, en este trabajo pretendo examinar algunas estrategias narrativas y sintácticas desarrolladas en un par de cintas chilenas que combinan el trabajo de memoria con el cuestionamiento material de la estabilidad del yo. Uno de los aspectos que me interesa destacar tiene que ver con las vinculaciones del asunto que acabo de describir y las construcciones de la infancia en relación con la memoria traumática. Dicho entramado está presente en la película de Carri y también en las cintas que pretendo usar para ejemplificar estos planteamientos. La primera de ellas es El edificio de los chilenos de Macarena Aguiló, hija de dos militantes del MIR. Ella vivió la experiencia del proyecto "Hogares", creado por ese movimiento político para dar hogares sustitutos a los niños cuyos padres habían optado por entregarse completamente a la causa política. El otro trabajo a analizar es El eco de las canciones de Antonia Rossi, filme que combina la experiencia del exilio con una mirada fragmentaria del presente. En ambas realizaciones me propongo trabajar con la materialidad fílmica, el aspecto formal en diálogo con la narración, que pone críticamente en tensión las concepciones de memoria, identidad e infancia.

Antes de iniciar el análisis propiamente tal, es preciso clarificar la aproximación conceptual a las ideas de identidad, memoria e infancia con las que voy a trabajar. En el caso de la identidad, me parece que hay dos asuntos que es importante mencionar, el primero tiene que ver con los debates actuales acerca de la cuestión de la identidad. Ya no podemos referirnos a esta como si fuera una entidad fija e invariable, pero tampoco renunciar a la relevancia de seguir revisando sus alcances, como bien propone Stuart Hall (2003), la identidad puede ser móvil y cambiante, un relato al que adscribimos -incluso estratégica y temporalmente-, pero en ese gesto de pertenencia hacemos al mismo tiempo una declaración política, y por eso sigue siendo relevante estudiar el concepto. Funciona además en distintos niveles: personal, grupal, social y, al igual que la memoria, opera en el diálogo que se produce entre estas capas. En segundo lugar, está la memoria, la cual es también un relato, una construcción que intenta conciliar un trazado lineal y ejemplificador con su comportamiento caótico e irreductible. Steve Stern distingue, para poner un nombre a estos dos comportamientos de la memoria, entre: la memoria emblemática y la memoria suelta, esta última desperdigada en miles de imágenes inasibles e inclasificables, en innumerables experiencias inenarrables que 
se rebelan ante la primera, versión consensuada y aglutinante del ejercicio mnémico ${ }^{1}$. En tercer lugar, la infancia, también como un constructo, elaborado tal como lo conocemos en la modernidad, cuyas delimitaciones están en estrecha relación con los ámbitos del poder y el control. En un estudio previo acerca de la infancia enfaticé sobre todo su manera de construirse conceptualmente desde la contradicción: el presente opuesto al pasado, la vigilancia a la autonomía, la potencia del lenguaje a la prohibición de hablar; estas oposiciones funcionan justamente en el intento "adulto" por integrar las fuerzas caóticas y desbordadas del infante, a una lógica sociocultural que lo sujete y lo redima.

En resumen, tanto la noción de identidad, como las de memoria e infancia con las que pretendo trabajar aquí serán entendidas como relatos, construcciones que ponen en tensión un nivel experiencial no reductible y una estructura social que quiere contenerlo. Esta complejidad es la que el lenguaje fílmico puede reflejar, al ser un lenguaje hecho de fragmentos o retazos que se confabulan para dar lugar a un discurso unitario. Como señalan Michelle Bossy y Constanza Vergara, refiriéndose a la lectura de Nora Catelli sobre Paul De Mann, en el documental autobiográfico: "el sujeto sería el resultado de una operación discursiva y no un punto de partida localizable en la realidad extratextual" (Bossy y Vergara, 2010, p. 15). Lo que me interesa es poner atención en las estrategias cinematográficas que no intentan enmascarar esta descomposición, sino que hacer de ella un elemento significante.

En el caso de los documentales de Aguiló y Rossi, es interesante que si bien podríamos situarlos en lo que Marianne Hirsch denomina postmemoria, ya que los protagonistas de los hechos traumáticos son los padres, ambas directoras se posicionan en un lugar autorizado de recuerdo, donde sus propias experiencias infantiles son válidas, caracterizadas por una complejidad material así como por la renuncia a una jerarquía rígida que organice estos componentes. Hay sin embargo, también una intención de aglutinar lo disperso en una voz desde y hacia la que confluyen. Así como Carri escoge a una actriz quien declara en cámara venir a representarla, pero no descarta situar su propio relato como complemento de este yo sustituto, las dos realizadoras chilenas proponen una voz estructurante que encamina la narración. Pero lo hacen de manera distinta. En El edificio de los chilenos es la misma Macarena Aguiló quien se hace cargo de esa voz en off, reafirmando una presencia, una continuidad entre quien recuerda y quien narra, una identidad que permanece y une el pasado y el presente. En cambio, El eco de las canciones se sostiene en un texto altamente poético y disperso, encarnado en una voz que si bien sugiere la presencia

1 Stern propone cuatro memorias emblemáticas que caracterizan el período post-dictatorial en Chile. Un poco más adelante haré uso de estas categorías para ver cómo los filmes estudiados desafían sus límites. 
real de la dueña de esos recuerdos confusos, es la de una actriz, y así se confirma en los créditos finales. El pacto autobiográfico descrito por Phillipe Lejeune sufre aquí una mínima dislocación, en la medida que tras proponer un acuerdo tácito de veracidad de aquello que muestra, utiliza luego herramientas propias de la ficción para restaurar el pasado. Si podemos situar la voz en off en una posición de poder, de perspectiva controladora, es interesante el punto de vista que enfatiza Michel Chion, al vincularla con la primordial de la madre que confiere "al mundo un orden de las cosas, dándole vida y nombre" (2004, p. 58). En este sentido, El eco de las canciones, aún anclada en un elemento sonoro que busca estructurar, se escabulle, al presentarse como real/no real, como propia y como ajena.

Por lo demás, y volviendo a Chion y sus consideraciones acerca de la voz sin cuerpo, en reiteradas ocasiones Macarena Aguiló no es solo una voz que narra, sino que también una imagen que entrevista, que dialoga, que actúa e interactúa. Antonia Rossi, no. Su imagen nunca aparece, su presencia es finalmente la acumulación de otras imágenes, de otros sonidos y, sobre todo, la superposición laberíntica, si se quiere, de un estado interior no permanente. Su voz es así la del acusmaser que describiera Chion, dotando de una atmósfera inquietante a todo el filme. En este sentido, propone también una reelaboración de la mirada infantil -que se recrea al reconstruir la experiencia del exilio- que no se apega a la "voz" autorizada, sino que la desmarca, ficcionalizándola.

Antes mencioné el trabajo de Steve Stern y su propuesta de memorias emblemáticas para la transición chilena. Las cintas que aquí analizo podrían incluirse dentro de la segunda y la tercera memoria, esto es, el período dictatorial como una "ruptura lacerante no resuelta” y como "prueba de consecuencia ética y democrática”. Pero por los mismos recursos que utilizan para reconstruir, precariamente, sus memorias, no pueden encajar totalmente en ninguna, reivindicando el valor de sentido contenido en las memorias sueltas que Stern les niega. Así también, sus narrativas cuestionadoras integran el valor del olvido, de la memoria clausurada, no como la describe Stern, en cuanto una cuarta memoria emblemática, sino como potencia de recuerdo. Las revisiones críticas que Macarena Aguiló hace de las decisiones de los militantes del MIR, el intercambio entre lo íntimo y lo colectivo que nutre su documental, así como la sintaxis desafiante que desarrolla Antonia Rossi, permiten leer la memoria y la identidad forjada gracias a ella, como territorios conflictivos y problemáticos.

Si lo confrontamos con El eco de las canciones, El edificio de los chilenos es, en muchos sentidos, un documental tradicional, que intenta conseguir cierta cohesión en el relato quebrado de su memoria, y para ello echa mano de recursos como la entrevista, las talking heads, o el retorno a lugares y personas relevantes para la reconstitución del recuerdo. Sin embargo, es posible individualizar ciertas escenas en las que la textura audiovisual se desmarca de este intento de narrativa sólida, para dar espacio a elementos disímiles que conviven y constituyen un entramado en el que el 
recuerdo aparece cargado de ambigüedades, en el que el pasado sugerido y el presente que lo moldea, se configuran en plena significancia. La llegada a Francia y el posterior reencuentro con su madre (Macarena Aguiló estuvo detenida en Villa Grimaldi y luego fue entregada a sus abuelos) es presentado a través de múltiples materiales que combinan grabaciones de infancia, fotografías y dibujos, con filmaciones de un viaje en bus por la ciudad. Solo vemos casas y edificios, y su presencia sugerida por las voces de ella y su madre, choca con un paisaje sin rostros ni rastros humanos. Es el inicio de una secuencia que da paso a una suerte de fragmentación identitaria concertada, donde la tendencia a la cohesión vuelve otra vez a desmembrarse por la variedad de materialidades. En la siguiente escena hay un recurso aún más radical, que no solo confronta elementos diversos, sino que también enlaza los niveles de lo personal y lo social, lo emocional y lo político. El recuerdo convocado son las reuniones de partido que sus padres tenían en el exilio. La voz en off dice: "la acompañaba a reuniones donde se hablaba cosas que a veces yo entendía”. Aparece una vez más esa cámara que mira hacia fuera (afuera del bus es ahora afuera de la ventana) e investiga el paisaje urbano. El registro de voces y risas de una niña (la propia Macarena), convive con la voz de un adulto que explica y argumenta sobre temas políticos. El audio es una grabación de una asamblea realizada el 2004 por los ex miembros del MIR y el sujeto que habla es Andrés Pascal. Así, las conversaciones de los padres y sus amigos son reemplazadas por la voz de la autoridad del grupo político, por la jerarquía, la orden de partido, y por un hecho que ocurre mucho más cerca del presente del filme que del pasado del recuerdo. Ella no habla, sino que ríe y balbucea. Y mira, pero hacia fuera. En estas escenas la curiosidad infantil, su perplejidad, contribuye a proponer un discurso habitado por múltiples registros que tienden a reunirse, pero a la vez se independizan, y es esa tensión dada por el movimiento de unión y separación la que otorga una riqueza significante al segmento. Así, el gesto por reinstalar el recuerdo refuerza su carácter ficcional o narrativo y se instala en una concepción de identidad que se nutre en la relación con otros proyectos identitarios, con el aspecto sociocultural de los mismos, y que desafía una noción subalterna de la infancia para presentarnos, por el contrario, una que se hace dueña de su discurso, y lo reivindica en su desintegración.

La película de Antonia Rossi se plantea mucho más radicalmente desde lo fragmentario, lo laberíntico y lo indeterminado. Nada en el filme nos sugiere la aspiración por llegar a una conclusión o a un lugar definitivo. El acto de recuerdo se regocija en su propia imprecisión. Además del uso reiterado de un lenguaje poético y metafórico (tanto en el sonido como en la imagen), sus recursos fundamentales son el trabajo de recopilación y recomposición de un archivo múltiple, que no le pertenece en sentido estricto, pero que constituye la materia prima de una textura de la memoria. Cintas antiguas, dibujos animados, documentales, películas caseras de otros, se entrelazan con músicas, sonidos y canciones. Lo que Bossy y Vergara identifican como "nostalgia reflexiva” favorece esta detención en lo mínimo, lo que se 
escabulle, lo que no se agota en el relato lineal. Y una de las características cruciales de este relato fílmico de infancia, es que viaja permanentemente del presente al pasado -y viceversa- desdibujando los límites entre uno y otro. El pasado se constituye una especie de "visitación" en el presente o, más bien, una presencia que lo habita. Esta posición se enfrenta con la que entiende a la infancia como una etapa a superar, como un lugar en la biografía que en determinado momento se abandona. Aquí la infancia vuelve o permanece $y$, de alguna manera, amenaza.

Solo por detenerme en alguna de las secuencias que permiten ejemplificar este modo de trabajar lo audiovisual, me referiré al segmento que he individualizado como "Noticias de Chile", que presenta, a su particular manera, cómo se viven desde su exilio las novedades acerca de las movilizaciones de mediados de los ochenta. El relato en off va entregando datos mínimos sobre un momento en particular: se escuchan pasos, una radio o un teléfono y sale alguien del ascensor, detalles que son graficados por imágenes de películas y animaciones que se vinculan tangencialmente con lo que ahí se dice. El lazo es metonímico y ello converge hacia una relación sonido-imagen que se potencia porque abre sus posibilidades significantes. Lo que se dice es lo que se dice, pero es más. Es su propio recuerdo pero es también otro, el suyo enlazado con los recuerdos de los demás, documentales y de ficción, conviviendo sin jerarquías. Luego la noticia: imágenes documentales de las protestas en Chile, y más tarde fotografías familiares donde los rostros salen del encuadre, una aproximación a lo propio que completa aquello que le falta o que quiere conservar oculto, con las voces, las miradas, las expresiones de los protagonistas de la resistencia de esos años. Es preciso destacar también que previo a esta secuencia tenemos largas tomas silenciosas de la actual vista desde su departamento en Santiago, y luego las mínimas descripciones van dando paso -como conjuro de entrada a un mundo secreto- al tránsito entre lo que ocurre hoy y lo que se busca recordar. Es una transición delicada que desdibuja límites claros, en una cinta donde también el presente es una especie de sueño o lugar indeterminado.

Mi intención primaria al iniciar este trabajo era explorar los vínculos entre la infancia, la memoria y la identidad en el documental autobiográfico, usando como material a revisar un par de filmes chilenos en los que la construcción de una primera persona podía ser útil para caracterizar dichas relaciones. Ambos trabajos reivindican el lugar de la infancia y desde esa posición privilegian una narrativa no lineal, basada en la fragmentación y la tensión entre esa energía independiente de lo parcial y las intenciones por alcanzar cierto grado de cohesión. En este sentido, el lenguaje fílmico, que no enmascara sus artilugios, sino que hace presente la materialidad de sus componentes, se inscribe en una presentación del viaje mnémico como cuestionamiento de la identidad en el sentido de un formato rígido o de un contenedor que no admite desbordes. Por el contrario, esta forma de nombrar el yo, le permite situarse en los espacios de lo ambiguo, lo incompleto y lo inconcluso. Pero no 
por ello permanece en la esfera de lo puramente personal e íntimo; por el contrario, se construye sobre la base de intercambios entre esa zona privada y las interacciones con lo público, lo social y lo político. Proponiendo también un cruce -especialmente en la propuesta de Antonia Rossi- entre la infancia y el presente, un espacio intermedio en el que ambos se nutren y conviven.

En su texto "Cine y autobiografía. Problemas de vocabulario", Philippe Lejeune comenta críticamente las ideas de Elizabeth Bruss acerca de la imposibilidad de lo autobiográfico en el cine, por estar siempre sujeto a la "condena" de ser ficción: "El cine presenta la desventaja de poder ser documental, la imagen, de estar siempre ligada a una realidad. Ese niño a quien hago interpretar mi infancia, ese adulto en quien delego mi papel, esas escenas que reconstituyo, no son la realidad que pretenden ser" (2008, p. 19). Lo que planteo aquí es que justamente esta posibilidad o capacidad de ser documental o, en otras palabras, el coqueteo del registro audiovisual con una supuesta "realidad" preexistente, le permiten situarse en la opción por no pretender sustituir algo que esté fuera del mismo lenguaje del filme, sino que asumirse como lo que es, un relato, tal como lo son la infancia, la identidad y la memoria; que puestos en diálogo pueden reivindicar en el cine el derecho a mirarse a sí mismo. 


\section{Referencias bibliográficas}

Bossy, M. y Vergara, C. (2010). Documentales autobiográficos: memoria y autorrepresentación. Santiago: Fondo de Fomento Audiovisual del Consejo de la Cultura y las Artes.

Chion, M. (2004). La voz en el cine. Madrid: Cátedra.

Hall, S. (2003). Introducción: ¿quién necesita identidad?. En Hall, S. y du Gay, P. (Comp.), Cuestiones de identidad cultural (pp. 13-39). Buenos Aires: Amorrortu.

Hirsh, M. (1997). Family Frames. Photography, Narrative and Postmemory. Cambridge-London: Harvard University Press.

Lejeune, P. (2008). Cine y autobiografía, problemas de vocabulario. En Gutiérrez, G. (Ed.), Cineastas frente al espejo (pp. 13-26). Madrid: T\&B.

Stern, S. (2000). De la memoria suelta a la memoria emblemática: hacia el recordar y el olvidar como proceso histórico (Chile, 1973-1998). En Garcés, M. et. al. (Comp.), Memoria para un nuevo siglo. Chile, miradas a la segunda mitad del siglo XX (pp. 11-33). Santiago: ECO-LOM, Usach. 